\title{
Description of the reproductive behavior of Symphysodon aequifasciatus (Cichlidae) in captivity
}

\author{
Douglas da Cruz MATTOS ${ }^{*}$, Rafaela SCRENCI-RIBEIRO², Leonardo Demier CARDOSO ${ }^{1}$, \\ Manuel Vazquez Vidal JUNIOR ${ }^{1}$ \\ ${ }^{1}$ Universidade Estadual do Norte Fluminense Darcy Ribeiro, Laboratório de Zootecnia, Campos dos Goytacazes, RJ, Brasil. \\ ${ }^{2}$ Universidade Estadual do Norte Fluminense Darcy Ribeiro, Setor de Estudos de Etologia, Reintrodução e Conservação de Animais Silvestres, Laboratório de Ciências Ambientais, \\ Campos dos Goytacazes, RJ, Brasil. \\ *Corresponding author: douglas_uenf@yahoo.com.br
}

\section{ABSTRACT}

The blue discus (Symphysodon aequifasciatus) is often sold for ornamental purposes. It is a neotropical cichlid from South America, which is native to the rivers of the Amazon basin of Brazil, Peru and Colombia. The purpose of this study was to characterize the reproductive behavior of $S$. aequifasciatus and identify features that can later be used by breeders to facilitate the handling and reproduction of this species in captivity. The experiment was divided into two stages: the first dealt with partner selection and couple formation to observe the behaviors of territoriality, pursuing, fleeing, biting, stay, protecting and cleaning of the substrate. The second stage documented mating behavior, nesting and parental care, to observe vibration, spawning, permanence with the offspring, aeration of eggs, cleaning of spawning, color change and shift-taking in parental care. The results of the study allowed identifying disputes for and establishment of territory, as well as the selection and cleaning of the substrate for spawning performed by both sexes. The parental care was observed from spawning in the substrate until the care for the larvae. It was found that the reproductive success of this species is closely linked to biparental care observed during the entire reproductive process and early stages of the hatchings.

KEYWORDS: Amazonian Fish, Ornamental Fish, Larviculture, Reproduction, Behavior

\section{Descrição do comportamento reprodutivo de Symphysodon equifasciatus (Cichlidae) em cativeiro}

\section{RESUMO}

Dentre as espécies de ciclídeos neotropicais comercializados para ornamentação, destaca-se o acará-disco (Symphysodon aequifasciatus), que é um ciclídeo neotropical originário da América do Sul, pertencente aos rios da bacia Amazônica do Brasil, Peru e Colômbia. Este estudo caracteriza o comportamento reprodutivo do acará disco (S. aequifasciatus) identificando características que posteriormente possam ser identificadas por criadores e utilizadas para facilitar o manejo e reprodução desta espécie em cativeiro. O experimento foi dividido em duas etapas, a primeira com a escolha de parceiro e formação do casal, e a segunda com acasalamento, desova e cuidado parental. Na primeira etapa foram observados os comportamentos de territorialidade, perseguição, fuga, mordida, permanência, proteção e limpeza do substrato, enquanto que na segunda etapa os comportamentos observados nesta etapa foram: tremor, desova, permanência com a prole, aeração dos ovos, limpeza da desova, mudança de coloração e revezamento do cuidado parental. Como resultado foi possível constatar disputa e estabelecimento de território, bem como a seleção e limpeza do substrato para a desova realizada por ambos os sexos. O cuidado parental foi observado desde a desova no substrato até o cuidado com as larvas e o sucesso reprodutivo desta espécie está intimamente ligado ao cuidado biparental observado por durante todo o processo reprodutivo e estágio inicial dos filhotes.

PALAVRAS ChaVE: Peixe Amazônico, Peixe ornamental, Larvicultura, Reprodução e Comportamento 


\section{INTRODUCTION}

Ornamental fish farming for decorative purposes and gardens is a branch of fish production (Gomes 1997). The activity has high commercial value and there is strong demand for species in the Brazilian and international markets (Lima et al. 2001).

Ornamental aquaculture activities are growing and there is always demand for new species. Producers are constantly looking for species with different sizes and color patterns to increase sales. Nevertheless, most species are collected in the natural environment, there are no protocols for production in captivity and fish capture from the wild (extraction) is the preferred method for obtaining fish. For fish farming and conservation purposes, information is needed about the ecology, diet, behavior, and reproductive habits of ornamental species and an understanding of the interactions of these factors.

There is strong commercial demand for neotropical cichlids intended for ornamental purposes, but little information is available about their gonadal development and reproduction (Dias 2001). One of the important species of neotropical cichlids sold for ornamental purposes is the discus (Symphysodon aequifasciatus Pellegrin, 1904). It is a neotropical cichlid from South America, native to the rivers of the Amazon basin of Brazil, Peru and Colombia (Wattley 1991). Symphysodon aequifasciatus is about $20 \mathrm{~cm}$ long, and has a body with a discoid shape and is found in a broad range of colors. They live in shoals and their diet is based on small crustaceans, larvae and insects (Santos et al. 2006). The $S$. aequifasciatus is a kind of biparental species, characterized by maintaining adhesive eggs and the larvae on the substrate. The parental care is only terminated when the offspring reach independence (Wattley 1991).

The understanding of the reproductive process is an essential part of the study of the biology of a species (Silva and Esper 1991), since it can lead to a decrease in capture from their natural environment. There is little knowledge about the discus' reproductive behavior in nature and very little relevant information about its behavior in captivity (Schütz and Barlow 1997). The purpose of this study was to characterize the reproductive behavior of discus fish in captivity and identify characteristics that can be used by breeders to facilitate the handling and reproduction of this species.

\section{MATERIALS AND METHODS}

Observations of the discus' reproductive behavior were carried out in the aquaculture sector of the Universidade Estadual do Norte Fluminense Darcy Ribeiro (UENF), for sixteen consecutive months (from April 2013 to July 2014), based on the ad libitum methodology proposed by Altmann (1974).

Males and females were used (42 adult individuals), which belonged to the staff of UENF's aquaculture sector. The work was divided into two stages: the first dealt with partner selection and couple formation, and the second with mating, spawning and parental care.

For the first stage, the discus were stored in experimental tanks with $50 \mathrm{~L}$ capacity and each tank was equipped with an aeration system and a foam filter. The fish were acclimated for one month after which the animals were selected for this study. In the second, the experimental units used white PVC pipes $30 \mathrm{~cm}$ long and $6 \mathrm{~cm}$ in diameter, which could serve as a substrate for future spawning.

In all the stages, the water was siphoned and renovated weekly, when $10 \%$ of the total volume was renovated. The tanks were housed in a closed area, with heaters to maintain the temperature within the species' comfort range $\left(28^{\circ} \mathrm{C}\right)$. The diet used specific commercial food for the species, in the amount of $5 \%$ of body weight daily, offered in three meals at 8 a.m., 11 a.m. and 4 p.m. To supplement the diet, live adult Artemia brine shrimp Artemia salina (Linnaeus, 1758) were offered, after the second daily feeding.

The water quality was monitored weekly and was maintained as follows: temperature $28.3 \pm 0.9^{\circ} \mathrm{C}$; dissolved oxygen $5.6 \pm 1.1 \mathrm{mg} \mathrm{L}^{-1}$ measured with oximeter (550A, YSI, Yellow Spring, OH, United States of America); pH $6.8 \pm 0.6$ measured with ( $\mathrm{pH} 100$, YSI, Beijing, China) and ammonia parameters were measured with a colorimetric kit (Labcontest toxic ammonia, Alcon, Camboriú, Santa Catarina, Brazil).

\section{Partner choice and formation of the couple}

To form couples, 42 adult individuals were used with average total length of $13.09 \mathrm{~cm}$, average height of 10.39 $\mathrm{cm}$ and average weight of $62.15 \mathrm{~g}$. They were divided into seven experimental tanks with six fish per experimental unit. The distribution of six specimens per tank was determined because the species does not present secondary sexual dimorphism, which is necessary to the natural formation of couples. The behaviors were considered to be characteristic of the species when performed by $100 \%$ of these couples. The fish were observed for behaviors of territoriality, pursuing, fleeing, biting, stay, protecting and cleaning of the substrate (Table 1). All of the couples were evaluated for one hour in the morning and one hour in the afternoon.

Persistent cleaning of the substrate was characterized as behavior that indicated couple formation and when this occurred the pair were separated to another tank for the second stage of the study, which began after 15 couples had formed. 
Table 1. Steps, behaviors and definitions of the evaluated characters in Symphysodon aequifasciatus

\begin{tabular}{|c|c|c|}
\hline Step & Behavior & Definition \\
\hline \multirow{7}{*}{$\begin{array}{l}\text { Choice of partner and } \\
\text { couple formation }\end{array}$} & Biting & $\begin{array}{l}\text { Invested behavior and mouth compression on the mouth or body of } \\
\text { another individual. }\end{array}$ \\
\hline & Attack & Attack behavior of an individual on the other. \\
\hline & Pursuing & When dominant fish chased other fish persistently throughout the tank. \\
\hline & Fleeing & When the submissive individual fled the chase of the dominant. \\
\hline & Isolation & $\begin{array}{l}\text { Individuals separated themselves from the rest of the shoal and are isolated in a } \\
\text { spot of the tank. }\end{array}$ \\
\hline & Territory defense & Expulsion of any other individual who approaches the chosen location. \\
\hline & Protecting & $\begin{array}{l}\text { Behavior of protecting the partner of the approach of another individual } \\
\text { from the shoal. }\end{array}$ \\
\hline \multirow{9}{*}{ Mating, spawning and parental care } & $\begin{array}{l}\text { Cleaning of the substrate for } \\
\text { spawning }\end{array}$ & Scraping the location chosen with the help of mouth. \\
\hline & Tremor & When individuals close to the time of spawning strove the body with tremors. \\
\hline & Rehearsal & Characteristic ritual of spawning, but without release of oocytes. \\
\hline & Spawning & Posture of oocytes after fertilization. \\
\hline & Parental care & Care for the eggs and later for the larvae. \\
\hline & Spawning cleaning & Removal with the mouth of the eggs, apparently unviable. \\
\hline & Aeration & $\begin{array}{l}\text { Movement of water over eggs and larvae, made by the couple with the help of } \\
\text { the mouth and pectoral fins. }\end{array}$ \\
\hline & Color change & Total change of animal color reaching dark color shades. \\
\hline & Relay of parental care & When the fish relay in caring for spawning and later the larvae. \\
\hline
\end{tabular}

\section{Mating, spawning and parental care}

In this stage, 15 couples kept in experimental tanks were used. The male fish used in this step had average total length of $14.62 \pm 0.12 \mathrm{~cm}$, average height of $10.99 \pm 0.09 \mathrm{~cm}$ and average weight of $83.1 \pm 0.11 \mathrm{~g}$, females had an overall average of $11.50 \pm 0.14 \mathrm{~cm}$, average height of $9.79 \pm 0.12 \mathrm{~cm}$ and average weight of $41.05 \pm 0.17 \mathrm{~g}$. After the couples began to reproduce, ten spawns of random couples and at different periods were photographed to obtain images for subsequent counting of eggs with the help of computing. The behaviors observed in this phase were: vibration, spawning, stay, aeration, spawning cleaning, color change and division of parental care (Table 1). All couples were evaluated over a period of two hours in the morning and two hours in the afternoon.

\section{RESULTS}

\section{Partner selection and couple formation}

When the adult males and females were placed in the experimental tanks for the formation of couples they displayed behavior of dominance of the shoal, with some individuals chasing others that fled. The dominated fish usually sought shelter behind the filter foam to hide from the dominant fish. After about three days, the establishment of an hierarchy within the shoal was noted, and it was possible to identify the dominant and dominated fish, but at this stage it was not possible to distinguish male from female individuals. The beginning of couple formation began 45 days after the allocation of individuals to the experimental units and it was marked by the choice of each partner. Individuals separated themselves from the shoal and isolated at a specific point of the tank, always close to thermostats, substrates or the foam filter. Once the couple was established, it defended its territory, expelling any other individual that approached the chosen location. It was also observed that both the male and the female prevented other fish from approaching the shoal and their respective partner.

\section{Mating, spawning and parental care}

In the days before spawning, the couple chose a spot on the wall of the tank, in the substrate or even in the foam of the filter, and began cleaning it with repeated "mouthings". This behavior varied in duration from $1 \mathrm{~h}$ to 3 days. As spawning approached, body trembling behavior was observed in both individuals. This behavior characterized the period prior to spawning. Another evidence of this period was the visible prolapse of the urogenital papilla.

A few minutes before the beginning of spawning the couple was observed conducting a "spawning rehearsal", in which they performed the entire characteristic ritual of spawning with the inclined body and belly in contact with the substrate, but with no release of oocytes.

Then, as the female truly released the oocytes in the substrate, the male performed the same movements as the female, releasing the sperm on the oocytes to conduct fertilization. This process of the release of oocytes and sperm 
lasted about an hour. The count verified an average of 164 oocytes per spawning. After spawning, the couple presented parental care of the eggs (Figure 1).

During this period the couple conducted "aeration" to oxygenate the eggs, with light wavy movements of the fins near the eggs. This process of oxygenation also occurred with the movements of their mouths and movement of water near the eggs. The eggs hatched 62 to 74 hours after spawning. The caring behavior extended after hatching (Figure 2). The couple cared for the larvae, which after hatching adhered to the substrate for about four days.

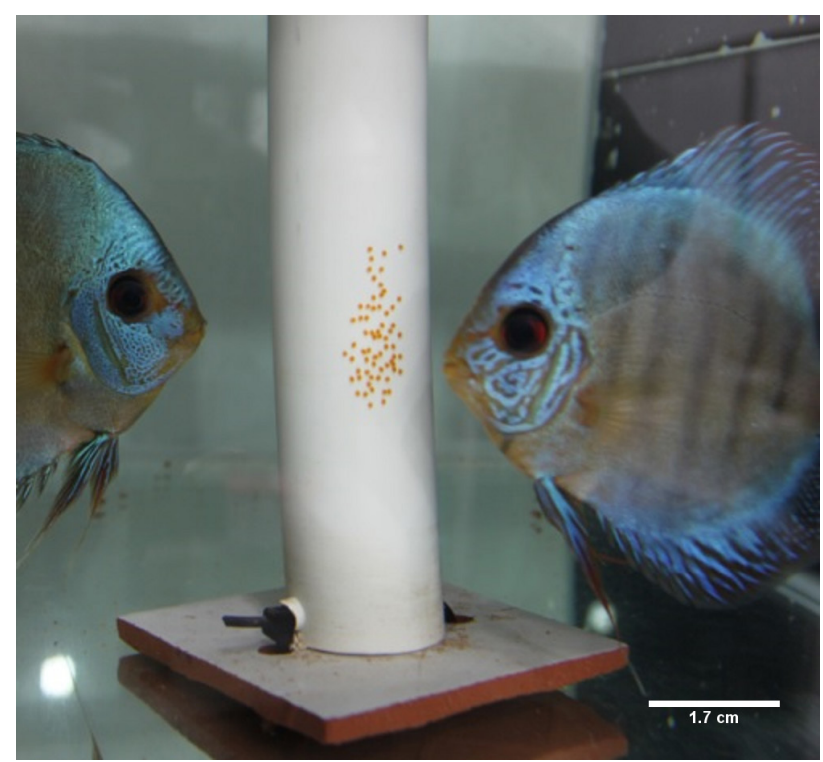

Figure 1. After spawning, the couple is presenting parental care of the eggs. This figure is in color in the electronic version.

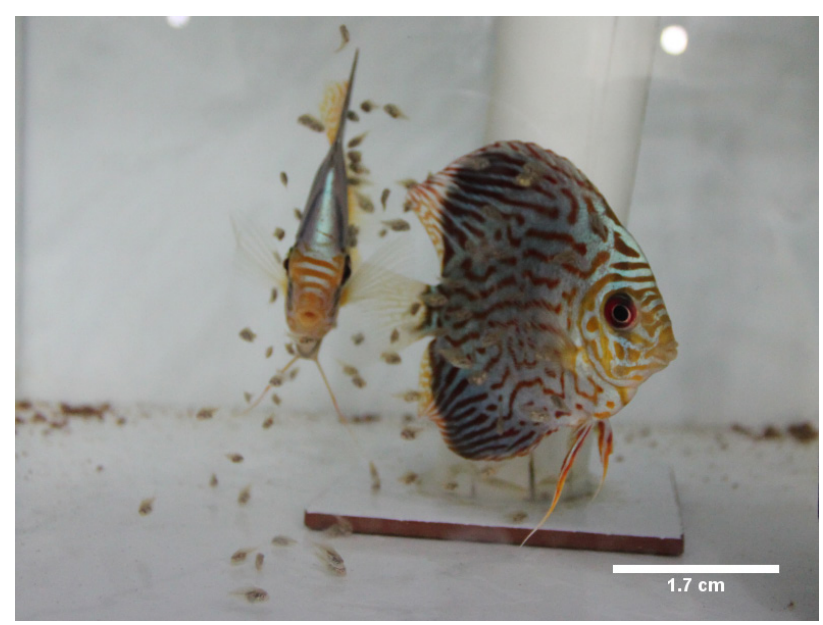

Figure 2. The caring behavior is extended after hatching. This figure is in color in the electronic version.
As the larvae developed, they began swimming in an errant way, falling off the substrate. The parents were observed collecting the larvae in their mouths and returning them to the substrate. At this stage, the parents had darker shades in their color patterns, which attracted the offspring to their parents because the discus larvae at the beginning of oriented swimming exhibit negative phototaxis, in other words, they are attracted to darker objects.

With the subsequent development of larvae they began horizontal swimming and the offspring fed themselves on parental mucus, swimming around the parents. It was also observed that the parents took turns caring for the offspring. At times the male took care of the offspring while the female fed, and at others, the female took care of the offspring while the male fed. The parents took care of the offspring until they began to ingest inert food.

About 20 days after hatching, the offspring were separated from their parents and placed in another tank. Eight to ten days after removal of the offspring the couple began a new spawn, repeating the entire reproductive cycle. When offspring remained with the parents for more than 20 days after hatching, it was observed that some couples ate these offspring and afterwards began a new cycle culminating in a new spawning.

\section{DISCUSSION}

The fish placed in experimental tanks for couple formation initially displayed territorial behavior, even before the period of partner selection. The observed behavior of pursuing and fleeing was characterized as being due to the establishment of a hierarchy within the shoal, and after this was established the partner selection began. Chasing behavior was also observed by Alves et al. (2009) for cockatoo cichlid Apistogramma cacatuoides Hoedeman, 1951 during the couple formation period. Alves et al. (2009) concluded that first adding the female in the formation tanks significantly reduced the observation of chasing behavior. However, this strategy could not be applied to individuals of $S$. aequifasciatus due to initial difficulty in sex identification because of the absence of apparent sexual dimorphism.

The reproductive strategy of $S$. aequifasciatus during partner selection and couple formation is characterized by territorial defense and protection of the partner. This reproductive behavior is typical of neotropical cichlids, which are also characterized by parental care with spawning and later for the larvae.

Males in many cichlid species (Cacho et al. 1999; Câmara 2004; Alonso et al. 2011) commonly perform territorial defense. In cichlids in captivity Archocentrus nigrofasciatus (Günther, 1867) curiously only the female performs territorial 
defense (Alonzo et al. 2001). However, unlike other cichlids, $S$. aequifasciatus of both sexes displayed territorial defense from the dominance of the shoal until after couple formation.

For angelfish Pterophyllum scalare Lichtenstein, 1823 (Cacho et al. 1999), the males perform cleaning for spawning and for Apistogramma agassizii Steindachner, 1875 (Romer 2001), in which females are responsible for cleaning for spawning. Both males and females of $S$. aequifasciatus performed cleaning of the substrate chosen to lay their eggs, similar to that observed in Cichlasoma dimerus Heckel, 1840 (Alonso et al. 2011).

Unlike the observation of $S$. aequifasciatus in the wild conducted by Rossoni et al. (2010), which characterized the spawning of discus to have more than 1,000 eggs per female, the discus fish in captivity presented partitioned spawning throughout the experimental period and produced an average of 208.5 eggs per female. This behavior of continuous spawns may have been influenced by the fact that the physicalchemical parameters of the water were kept within the comfort requirements for the species, providing an environment suitable for reproduction throughout the experimental period.

The number of oocytes released by the females during the experimental period were also different than the values found by Rossoni et al. (2010), this difference may be due to the higher frequency of spawning observed for females kept in captivity where fewer oocytes are released in successive spawns and not just during a single spawning.

The care for the spawning was done by both sexes, similarly to C. dimerus (Alonso et al. 2011). The observation of shifts by the male and female in relation to cleaning care and aeration of the spawning and later in the care of the larvae was also observed for other species of cichlids maintained and observed in captivity such as the Laetacara sp. (Teresa and Gonçalvesde-Freitas 2011). In general, the cichlid species that display biparental care characteristics are also known for a long period of parental care (Keenleyside 1991).

With the development of the larvae and the beginning of errant swimming, it was possible to observe darker shades in the color patterns of the parents. According to Pereira (1976), this color change occurs to emphasize the body and to attract the larvae, which facilitates the orientation and location of the parents by the larvae, facilitating the initiation of feeding. This fact is explained by the characteristic of this species in which after the offspring absorb the yolk and begin oriented swimming, they also begin to feed on epidermal mucus secreted by the parents. According to Chong et al. (2005) amino acids and essential substances in the mucus are extremely important in the early days of larval development. This same behavior is also known in neotropical species of S. discus, midas cichlid Cichlasoma citrinellum (Günther, 1824) and in two species from Madagascar and India; orange chromide Etroplus maculatus (Bloch, 1795) and pearlspot E. suratensis (Bloch, 1790) lineage (Hildemann 1959; Noakes 1979; Noakes and Barlow 1973; Ward and Wyman 1977). According to Buckley et al. (2010), males are generally darker than females and therefore the larvae feed more with the former (Buckley et al. 2010).

\section{CONCLUSION}

The dispute for and establishment of territory, as well as the selection and cleaning of the substrate for the spawning is performed by both sexes and suggests that the reproductive strategy is characterized by territoriality and parental care and that there is cooperation between the parents in all activities. The parental care began from spawning in the substrate and biparental care was observed throughout the care period for the eggs and for the care of the larvae. The reproductive success of this species is due to the biparental care observed throughout the reproductive process.

\section{ACKNOWLEDGMENTS}

We thank the aquaculture sector of Universidade Estadual do Norte Fluminense Darcy Ribeiro for logistic support and assistance. Douglas Mattos and Leonardo Cardoso were supported by scholarship from Coordenaçáo de Aperfeiçoamento de Pessoal de Nível Superior (CAPES) and Rafaela Screnci-Ribeiro was supported by scholarship from Fundação de Amparo à Pesquisa do Estado do Rio de Janeiro ( FAPERJ).

\section{REFERENCES}

Alonso, F.; Cánepa, M.; Moreira, R.G.; Pandolfi, M. 2011. Social and reproductive physiology and behavior of the Neotropicas cichlid fish Cichlasoma dimerusunder laboratory conditions. Netropical Ichthyology, 9:559-570.

Alonzo, J. A.; Mckaye, K. R.; Van Den Berghe, E. R. 2001. Parental defense of young by the convict cichlid, Archocentrus nogrofasciatus, in Lake Xiloá, Nicaragua. Journal of Aquariculture and Aquatic Sciences, 9:208.

Alves, F. C. M., Rojas, N.E.T., Romagosa, E. 2009. Reproduction of the "Amazonic Dwarf-Cichlid", Apistogramma Cacatuoides, Hoedeman, 1951 (Perciformes: Cichlidae) in laboratory. Boletim Instituto de Pesca, 35: 587-596.

Altmann, J. 1974. Observational study of behavior: sampling methods. Behavior, 69:227- 263.

Buckley, J.; Maunder, R. J.; Foey, A.; Pearce, J.; Val, A. L. 2010. Sloman, K. Biparental mucus feeding: a unique example of parental care in an Amazonian cichlid. Journal of Experimental of Biology, 213:3787-3795.

Cacho, M. S. R. F.; Yamamoto, M. E.; Chellappa, S. 1999. Comportamento reprodutivo do acará bandeira, Pterophyllum scalarae Cuvier \& Valenciennes (Osteichthyes, Cichlidae). Revista Brasileira de Zoologia, 16:653-664. 
Câmara, M. R. 2004. Reproductive Biology of Neotropical Ornamental Acara disc, Symphysodon discus Heckel, 1840 (Osteichthyes: Perciformes: Cichlidae). Tese de doutorado. Universidade Federal de São Carlos, São Carlos, São Paulo. 135p.

Chong, K.; Ying, T. S.; Foo, J.; Jin, L. T.; Chong, A. 2005. Characterization of proteins in epidermal mucus of discus fish (Symphysodon spp.) during parental phase. Aquaculture, 249:469-476.

Dias, R. L. 2001. Desenvolvimento gonadal do acará bandeira, Pterophyllum scalare (Lichtenstein, 1823), um ciclideo neotropical. Dissertação de mestrado. Universidade Federal do Rio Grande do Norte, Natal, Rio Grande do Norte. 96p.

Gomes, S. 1997. O aquário Marinho e as Rochas Vivas. Editora Camargo Soares Ltda, São Paulo, 256p.

Hildemann, W. H. 1959. A cichlid fish Symphysodon discus, with a uniue nurture habits. The American Naturalist, 93:27-34.

Keenleyside, M. H. A. 1991. Cichlid fishes: behavior, ecology and evolution. Chapman e Hall, Great Britain, 378p.

Lima, A. O.; Bernardino, G.; Proença, C. E. M. 2001. Agronegócio de peixes ornamentais no Brasil e no mundo. Panorama da Aqüicultura, 65:14-24.

Noakes, D. L. G.; Barlow, G. W. 1973. Ontogeny of parentcontacting in Young Cichlasoma citrinellum (Pisces, Cichlidae). Behaviour, 46:221-55.

Noakes, D. L. G. 1979. Parent-touching behavior by young fishes: incidence, function and causation. Environmental Biology of Fishes, 4:389-400.

Pereira, R. 1976. Peixes de nossa terra. Nobel, São Paulo, 129p.
Romer, U. 2001. Cichlid Atlas 1: Natural History of South América Dwarf Cichlids. Mergus Verlag, Alemanha, 1310p.

Rossoni, F.; Amadio, S.; Ferreira, E.; Zuanon, J. 2010. Reproductive and population parameters of discus fish Symphysodon aequifasciatus Pellegrin, 1904 (Perciformes: Cichlidae) from Piagaçu-Purus Sustainable Development Reserve (RDS-PP), lower Purus River, Amazonas, Brazil. Neotropical Ichthyology 8: 379-383.

Santos, G. M.; Ferreira, E. J. G.; Zuanon, J. A. S. 2006. Peixes Comerciais de Manaus. Ibama/Pró Várzea, Amazonas, 141p.

Schütz, M.; Barlow,G.W. 1997. Young of the Midas cichlid get biologically active nonnutrients by eating mucus from the surface of their parents. Fish Physiology and Biochemistry, 16:11-18.

Silva, R. M. P. C. da; Esper, M. L. P. 1991. Observações sobre o desenvolvimento citomorfológico dos ovários de tainha, Mugil platanus (Günther) da Baía de Paranaguá (Brasil). Acta Biologica Paranense, 20:15-39.

Teresa, F.B.; Gonçalves-de-Freitas, E. 2001. Reproductive behavior and parental roles of the cichlid fish Laetacara araguaiae. Neotropical Ichthyology, 9:355-362.

Ward, J. A.; Wyman, R. L. 1977. Ethology and ecology of cichlids fishes of the genus Etrolopusin Sri Lanka: preliminary findings. Environmental Biology of Fishes, 2:137-45.

Wattley, J. 1991. Discus for the perfectionist. 1st ed. T.F.H Publications, Neptune City, 128p.

Recebido em 03/02/2016

Aceito em 16/05/2016 